DOI: $10.15503 /$ jecs20162.388.397

\title{
HOW ARE EDUCATION AND MINORITY STATUS CONNECTED: THE CASE OF ROMANIAN ROMA IN WROCŁAW \\ MICHALINA MARCZAK

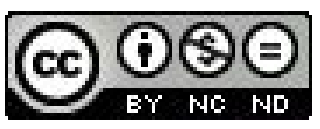 \\ Institute of Psychology, University of Wroclaw, J. W1. Dawida Street 1, 50-527 Wroclaw E-mail address: michalina.marczak@gmail.com
}

\begin{abstract}
This paper aims to discuss the connection between compulsory schooling and minority status, and how they are related to differential performance of minorities in national education systems. After describing the theoretical framework based on the works of John Ogbu, I will attempt to present how his Cultural-Ecological Theory of School Performance refers to Romanian Roma community in Wrocław, Poland, which is a group systematically excluded from the dominant society. The analysis suggests that systemic forces act against Roma. This is marked by discrimination towards them in schools and in the labour market. On the side of Roma, mistrust in public institutions, fear of loosing cultural identity and seeing escaping the pariah status as unobtainable leads to lack of investment in formal education.
\end{abstract}

Key words: Roma, minority education, Cultural-Ecological Theory of School Performance.

\section{INTRODUCTION}

Education and minorities

Education understood as "the transmission of the values and accumulated knowledge of a society" (Safra, \& Yeshua, 2002, pp. 1) had been crucial for every society's success long before formal schooling emerged. Peoples across the world passed on and utilised their traditional knowledge in order to thrive and develop. Though many a knowledge system was exchanged on more or less equal basis and integrated with each other thus leading to further technological developments, the knowledge of other groups had not been recognised as valuable. This was often the case in the colonial times when white incomers made considerable effort to eradicate not only the knowledge systems of the conquered peoples but also the whole populations (e.g. Levi-Strauss, 1984; Lindqvist, 1997). Under cruel colonial policies and expansion of intrusive populations, many aboriginal groups became ethnic minorities in the newly formed states where soon the physical annihilation was repla- 
ced by a strong urge of assimilation of minorities into the dominant society. Schooling usually became a powerful tool of manipulation transmitting the values of the dominant group and uprooting traditional knowledge of minorities (Giroux, 1981). Furthermore, school curricula for aboriginal groups were constructed based on racist prejudices in order to keep the indigenous groups at the low end of the social hierarchy (Welch, 1988). Limits of schooling were drawn between teaching rudimentary skills to provide a steady stream of cheap labour and introducing "savages" to Christianity (Welch, 1988) in line with the Jesuits" dictum: "Give me a child until he is seven, and I will guarantee his lifelong loyalty to the Roman faith" (Koehl, 1975). In non-colonial states, minorities often experienced unification with the dominant groups which was the case in Norway, for instance, where the Saami people were subject to intensive Norwegianisation (Eidheim, 1998). National education can thus be viewed as an instrument for colonising other ways of learning as well as forming a cohesive national culture but first and foremost, as approached through the notions within the Marxist tradition, especially Gramsci's theory of hegemony: "[n]ot only could it play an important role in furnishing industry and the state bureaucracy with personnel trained with the right skills and appropriate attitudes, but also it was of inestimable value for the dominant social classes in establishing their hegemony over the population at large" (Green, 2013, p. 86). It is not surprising then, that many ethnic minorities today mistrust state-based institutions including the educational ones. This, in turn, affects their school performance and perpetuates their exclusion from the mainstream society. The relationship between minorities and education is complex, however, as may be illustrated by secondary education rates in the U.S. where, as of 2007, 58\% of Asian Americans aged between 25 and 29 held a bachelor's degree comparing to 33\% of whites, $17 \%$ of African Americans, 11\% of Hispanics and 9\% of American Indians (Ryu, 2009). To understand this connection, I will first clarify the notion of ethnic minority and subsequently outline John Ogbu's Cultural-Ecological Theory of School Performance.

\section{Ethnic minority}

Ethnic minority can be defined as a group smaller in numbers than the rest of the population in a society, a group which does not have political dominance and which is seen as a distinct ethnic category (Eriksen, 2010). Eriksen (2010) draws attention to notions of relativity and relationality of the minority status - minority can only exist in relation to majority and only under given system boundaries which are nowadays most often defined by state boundaries. This is why ethnic minority status is fluid and subject to change when state boundaries are redrawn. It was argued, however, that minority should rather be defined from the power relations perspective than in terms of numerical representation - hence a minority is a group that occupies a subordinate power position compared to another group within the same society (Ogbu, \& Simons, 1998). 
Cultural-Ecological Theory of Minority School Performance

The power relations between groups are an important part of J. Ogbu's Cultural-Ecological Theory of Minority School Performance (1998) which aims to answer the question of differential performance of minorities in national education systems (Ogbu, \& Simons, 1998). The theory, which was developed based on the studies in the United States, considers the interaction between educational and societal environment as well as the dynamics of minorities' perceptions and responses to how they are treated. It makes strong objection to suggestions that some groups are genetically inferior than others in terms of their learning abilities or that some cultures are better at educating their youth, or that some languages are better adapted for transferring knowledge. The theory consists of two major parts: the system and community forces. The system is an umbrella term for (mis)treatment of minorities in education by the dominant population as well as structural barriers and discrimination minorities face in society. It consists of three forms: (1) educational policies and practices toward minorities, (2) treatment of minority students in schools and classrooms, and (3) rewards that members of minorities can expect to receive from society for their investment in education. The second major part of the theory, community forces help explain the variance in school performance among different minorities. Community forces concern minorities' perceptions of and responses to formal education. J. Ogbu suggests that these forces are constituted by four factors which he calls: (1) the frame of reference, (2) instrumental beliefs about the value of schooling, (3) relational beliefs about as well as interpretations of formal education and (4) symbolic beliefs about public education. To better explain different achievements of minorities in national education systems, J. Ogbu divides minority groups into: autonomous, voluntary and involuntary. The autonomous minorities are constituted by groups small in numbers which might be of different race, ethnicity, religion or language from the dominant groups. He believes that, even though they might experience some discrimination, they are not entirely dominated or oppressed, and their school performance does not differ significantly from that of the general population. Based on a group's history and the nature of mainstream society's involvement with the group acquiring the minority status, minorities are divided into voluntary and involuntary. Those who have relatively willingly immigrated to another country are called voluntary minorities. They hope for a better future in the new place of residence and do not perceive that they were forced to become a minority, at least not by the government and citizens of their new country. By contrast with their voluntary counterparts, involuntary minorities are groups who find themselves in subordinate position in society against their will - they have been conquered, colonised or enslaved. Additionally, Ogbu introduces the categories of refugees, migrant/guest workers, undocumented workers and binationals as well as descendants/later generations which are also useful in addressing the question of differential school performance. In general, J. Ogbu's research indicates that involuntary minorities suffer from more discrimination and do 
less well in school than voluntary minorities. Ogbu attributes this difference in school performance to the groups' developing different cultural models of the dominant group. Albeit J. Ogbu's theory fits well in the American setting, it might need some modification in order to apply it to the case of the Romanian Roma minority in Poland.

\section{ROMANIAN ROMA IN WROCŁAW}

The Romanian Roma community in Wrocław numbers approximately 200 people who live in an encampment of makeshift barracks on the outskirts of Wrocław. Members of the group cannot afford to rent flats and, since they do not have the Polish citizen status, they do not have access to social housing or rent allowance. By European standards, they live in extreme poverty, without permanent access to running water or electricity. In 2012 local authorities decided to demolish the barracks referring to the opinion of the municipal sanitary inspectorate about high risk of epidemics among the unvaccinated Roma. Under the pressure of NGOs and public opinion, city authorities withdrew from the decision and took the case to court instead which is to decide about the future of the encampment. The eviction trial against the Romanian Roma has been pending in the District Court in Wrocław since April 2013.

As Agata Ferenc and Maciej Mandelt (2014) report, the Romanian Roma arrived in Wrocław, a city of nearly 650,000 inhabitants in western Poland, in the mid-1990s escaping the increasing levels of poverty and persecution following the dissolution of the communist regime in Romania. Due to specific requirements concerning obtaining the residence permit such as presenting a proof of income as well as health insurance, the impoverished migrants could not register as residents of Poland. In consequence, they have long been denied access to basic public services, including, among others, healthcare and education. Their situation as illegal immigrants has further marginalised the already systemically excluded group. Through about 20 years of their stay in Poland, the group faced several forced evictions and saw their encampments demolished by the local authorities. Many people were detained and deported to Romania. Neither the evictions nor deportations were supported by court decisions. These illegal proceedings put a strain on the relations between the Romanian Roma and the authorities. The last illegal demolition of a Roma camp in Wrocław was executed in July 2015 in broad daylight, in the absence of the residents who, to their horror, returned in the evening to a pile of wood that was left in place of their homes. What has also been a characteristic part of the relations between the Romanian Roma and the dominant society, is the group's extremely low status among Polish citizens. Many regard Roma as "thieves" and "scum". One often hears that they are "lazy" and "dirty" and that "Gypsies don't want to work but send their children to beg on the streets instead". Furthermore, not only has the community experienced frequent threats and harassment from the supporters of 
neo-Nazi groups but many Roma have been verbally insulted and physically assaulted on the streets on a daily basis. They have been reluctant however to report their mistreatment to the police due to their high level of mistrust in public institutions as well as because of fear of retaliation.

\section{DISCUSSION}

Romanian Roma - what kind of minority?

Before I apply the Cultural-Ecological Theory of School Performance (Ogbu, 1998) to explore the case of the Romanian Roma community, let me discuss its authors' distinction of minority statuses. What J. Ogbu does not take into account, is the intersectionality between different minority types he distinguished. It is difficult to ascribe the Romanian Roma community to a specific category within his framework. The Roma left Romania for Poland in mid-1990s more or less voluntarily in hope for a better future but at the same time they have remained representatives of one of the most marginalised minorities in Europe, sometimes compared to African Americans (Greenberg, 2010). Not to mention the divisions within the Roma ethnic group the Polish Roma do not hold the impoverished Romanian Roma immigrants in high regard. And when one takes a closer look at the history of Roma people in Europe, clear distinction becomes even more complicated. They are believed to be descendants of high-caste groups who escaped north-west India around year 1300 fleeing the Islamic invasion (Hancock, 2010). They reached Europe in the 14th century and, after a long period of peaceful and mutually beneficial coexistence with the gadje (non-Roma), beginning from the 16th century, they have suffered from persecution and increasing restrictions (Taylor, 2014). Determined to save their cultural identity, they adopted a nomadic way of life. The situation of Roma was even worse in what is today Romania, where between the 14th and 19th century, Roma were enslaved and treated like cattle (Hancock, 2010). The twentieth century brought more tragic events to the history of Roma. Although the exact figures are difficult to estimate, historians suggest that the number of victims of Porajmos, the Romani genocide conducted by the Nazis, fall in between 0,5 and 1,5 million (Hancock, 2005). The suffering of Roma at the hands of Germans and their collaborators was not recognised in Holocaust literature as widely as Judeocide and it was argued that the exclusion of the Roma stretches so far that people tend to deny that Roma shared suffering with the Jews (Milton, 1991; Hancock, 2010).

According to J. Ogbu's typology, the Romanian Roma in Poland are descendants of refugees from India (to use the contemporary nomenclature) whose later generations could have been ascribed the status of the autonomous minority, and, at the same time, they are now an involuntary minority who became a voluntary minority through their migration to Poland, remaining an involuntary minority since they meet a similar level of animosity in Poland as 
in Romania (and possibly elsewhere in Europe). As J. Ogbu suggests (1998), the minority status should be ascribed to a group on the basis of careful analysis of the group's history. What stems from the brief description of Roma history presented above is long-term, deeply-rooted exclusion from the mainstream society, often founded on the racist arguments. Mistreatment, poverty and fleeing accompanied Roma for centuries, establishing their feeling of not belonging to the mainstream society and strengthening their culture which evolved against the culture of their oppressors. The dramatic events in the background of the Roma's acquiring their contemporary minority status allow us to conclude that Romanian Roma in Wrocław should be considered an involuntary minority. Based on this premise, what follows is the assumption of their poor school performance.

Roma and the national education system

From the historical perspective, the relation between Roma and national education systems has often been problematic. In some countries, including Poland, schools became places of forced assimilation of Roma children, especially after World War II. Their culture was deemed inferior by teachers and they were taught to conform with the mainstream society (Cahn, Chirico, McDonald, Mohácsi, Perić, \& Székely, 1999). Many experienced racism and mistreatment. Schooling opportunities that are offered to the Roma today have remained poor and schools are still subject to segregation (Greenberg, 2010). Many parents based on their own humbling experience with formal education decide, therefore, not to send their children to school. In Poland, as of 2011 , at least $14 \%$ of Roma aged 16 and above reported that they could neither read nor write and $17 \%$ of Roma children up to age 15 did not attend schools (European Union Agency for Fundamental Rights, 2014). Many Roma however are not adequately captured by official statistical tools. This is likely to be the case with the Romanian Roma community who, due to their position on the verge of Polish society, fail to be included in statistical measurements. The vast majority of the Romanian Roma community in Wroclaw are functionally illiterate (Ferenc, \& Mandelt, 2014). Few of them had had any schooling experience (usually negative) in Romania. Until mid-2014, children from the encampment community were not enrolled in any type of formal education. Even though Polish law grants children below the age of 18 the right to primary and secondary education regardless of their citizenship status, the legal obligations were difficult to implement in the case of children living in the encampment. The parents' reluctance towards formal schooling stemming from their negative experience of the Romanian school system as well as the lack of clear procedures for addressing the problem on the side of Polish social workers led to the neglect of the enrolment of Romanian Roma in the education system (Ferenc, \& Mandelt, 2014). Between 2013 and 2014, however, the children were encouraged to participate in informal classes organised by NGOs. During the classes they were taught basic literacy skills such as writing, reading and elementary mathematics. NGOs' dia- 
logue with the Department of Education, a body of the Wrocław City Council, resulted in developing a programme for schooling the children. Those, whose parents were willing to participate in the programme, were enrolled in primary school. According to A. Ferenc and M. Mandelt (2014), children were directed to attend individual classes (one-to-one units). Even if the aim of such classes was to enable the children to catch up with the mainstream curriculum and improve their language skills, such organisation of tuition might be considered as segregation since the children did not have a chance to interact with other pupils. What is more, the children were not assigned a cultural assistant who could make the integration with Polish traditions and mores easier and less stressful (Ferenc, \& Mandelt, 2014).

Romanian Roma's schooling in the light of the Cultural-Ecological Theory of School Performance

From the perspective of the Cultural-Ecological Theory of School Performance, "the system" acts against Roma in spite of Poland's adoption of the National Roma Integration Strategies advised by the EU (Farkas, 2014). Polish educational policies and practices are still fuelled by segregation, elitism and bureaucracy. Strong divisions between schools exist - the best schools being either private or difficult to get into. The centralised national system of final exams tends to bolster the discrepancy between schools, keeping the good students away from the bad ones and often leading to the "white flight". Even though funding that could help Romanian Roma integrate with the school system is available (from the Polish Ministry of Education or from different EU grants, for instance), the officials do not make the effort to apply for the money (which could finance the cultural assistants for the Roma, for example) (Ferenc, \& Mandelt, 2014). Another common practice is putting Roma children in schools for the mentally disabled, which might be the case for as much as $25 \%$ of Romani children attending schools in Poland (ERRC, 2002). Roma experience major discrimination in the classrooms - the treatment of Roma students by teachers is marked with prejudice and antipathy, and it is not seldom that they are bullied by other students (Cahn et al, 1999; ERRC, 2002; Puckett, 2005). Romanian Roma in Poland suffer from lack of employment opportunities. Even though, according to EU regulations, migrants within the EU have the right to work in Poland, employers are often unaware of this fact. In turn, if employed, Roma, are on short-term unofficial contracts. Their main source of income is begging, metal-scrap-collection and petty theft (Ferenc, \& Mandelt, 2014). Lack of school credentials does not fully explain Roma's exclusion from the job market because the problem stems also from discrimination in employment (O'Higgins, \& Ivanov, 2006). This mirrors the general hostility towards Roma among ethnic Poles. Attitudes towards Roma in Poland are more negative than they are towards any other national or ethnic minority in the country (Celinska, \& Gutkowska, 2014). Thus, formal education does not have much potential to improve the Roma's employment opportunities. 
Moreover, as mentioned earlier, the majority of Romanian Roma view formal education in a negative light. They have a deep-rooted mistrust in public institutions since historically they have rather experienced problems posed by the state than help from its side. The demolitions of their encampments, deportations, mistreatment by the police, the eviction process and a range of other unfortunate events established the pattern of Romanian Roma's avoidance of the official institutions. Roma oppose prejudiced practices against them at schools but lack knowledge about their rights and the means to execute them. In turn, they often believe that the only way to avoid mistreatment is dropping out of school (Cahn et al, 1999). They might compare Polish schools and schools in Romania and the results of this comparison might be in favour of Poland (European Union Agency for Fundamental Rights, 2014) but it is a matter of fact that Roma experience exclusion and abuse in both countries (Amnesty International, 2016). Their dual frame of reference remains negative - despite moving to a different country, they did not escape their pariah status and it is very unlikely that they will. They see the social and economic status of ethnic Poles as unobtainable for Roma no matter what investments in formal education. They also perceive schooling as harmful to cultural and language identity since they see it as a means of controlling their children's and their own lives and hindering children's participation in the economic activities of the family (Cozma, Cusos, \& Momanu, 2000). The analysis of the community forces, along with the system, sheds light on why Roma decide to stay away from formal schooling and hence remain the least educated ethnic minority in the country (European Union Agency for Fundamental Rights, 2014).

\section{CONCLUSION}

Roma have remained culturally distinct from the surrounding groups through the centuries of persecution. Despite strong pressure on assimilation, they have managed to preserve their language and practices. Paradoxically, it can be assumed that the mistreatment by the dominant groups strengthened their ethnic identity as Roma. Their strong opposition to the homogenisation processes during the formation of the contemporary states led to their stigmatisation and exclusion from society. They have kept challenging the state through their way of life which seems to be incongruent with the market economy. At the same time, their lifestyle on the verge of capitalism has been predominantly marked by poverty. On the one hand, Roma's evasion from the national education system helps them maintain cultural distinctiveness which was built in opposition to the gadjes' culture, on the other hand the lack of access to education might be one of the main factors contributing to their inability to exit the circle of poverty. In the last century, Roma have experienced different approaches of the state to minority groups, including genocide and displacement, and insistence on assimilation. Today, the introduction 
of more tolerant policies in Poland would have the power to finally break the vicious circle of marginalisation of Romanian Roma and empower them to live in dignity according to their cultural values. Education holds a great potential in addressing this issue but Roma people must be first recognised as equal actors and invited to co-construct culturally responsive schooling for their community.

\section{REFERENCES}

[1] Amnesty International (2016). Amnesty International Report 2015/16. The State of The World's Human Rights. London: Amnesty International.

[2] Cahn, C., Chirico, D., McDonald, C., Mohácsi, V., Peric, T., \& Székely, A. (1999). Roma in the Educational Systems of Central and Eastern Europe. In: C. Fényes, C. McDonald, \& A. Mészáros (Eds.), The Roma Education Resource Book (pp. 20-26). Budapest: Open Society Institute - Institute for Educational Policy.

[3] Celinska, K., \& Gutkowska, A. (2014). The Polish Roma: From a persecuted to a protected minority. International Journal of Comparative and Applied Criminal Justice, 38 (2), 157-171.

[4] Cozma T., Cusos, C., \& Momanu, M. (2000). The education of Roma children in Romania: Description, difficulties, solutions. Intercultural Education, 11 (3), 281-288.

[5] Eidheim, H. (1998). When Ethnic Identity becomes a Social Stigma. In F. Barth (Ed.), Ethnic Groups and Boundaries (pp. 39-57). Oslo: Universitetforslaget.

[6] Eriksen, T.H. (2010). Ethnicity and Nationalism. Anthropological Perspectives. London: Pluto Press.

[7] European Union Agency for Fundamental Rights (2014). Roma survey - Data in focus Education: the situation of Roma in 11 EU Member States. Luxembourg: Publications Office of the European Union.

[8] European Roma Rights Center (2002). The Limits of Solidarity. Roma in Poland after 1989. Budapest: European Roma Rights Center.

[9] Farkas, L. (2014). Report on discrimination of Roma children in education. Brussels: European Commission Directorate-General for Justice.

[10] Ferenc, A., \& Mandelt, M. (2014). Systemic Exclusion and Pathways to Integration. The Situation of the Romanian Roma living in Wroctaw. Wrocław: Nomada Association.

[11] Giroux, H.A. (1981). Ideology, Culture and the Process of Schooling. Philadelphia: Temple University Press.

[12] Green, J. (2013). Education and State Formation. Europe, East Asia and the USA. Basingstoke, UK: MacMillan.

[13] Greenberg, J. (2010). Report On Roma Education Today: From Slavery to Segregation and Beyond. Columbia Law Review, 110 (4), 919-1001.

[14] Hancock, I. (2005). Romanies and the Holocaust: A Re-evaluation and Overview. In: D. Stone (Ed.), The Historiography of the Holocaust (pp. 383-396).

[15] New York: Palgrave MacMillan.

[16] Hancock, I. (2010). Danger! Educated Gypsy: Selected Essays. Hatfield: University of Hertfordshire Press.

[17] Koehl, R. (1975). Cultural Imperialism as Education: An Indictment. Comparative Education Review, 19 (2), 276-285.

[18] Levi-Strauss, C. (1984). Tristes Tropiques. Middlesex: Penguin Books.

[19] Lindqvist, S. (1997). "Exterminate All the Brutes": One Man's Odyssey into the Heart of Darkness and the Origins of European Genocide. NY: The New Press.

[20] Milton, S. (1991). Gypsies and the Holocaust. The History Teacher, 24 (4), 375-387.

[21] Ogbu, J.O., Simons, H.D. (1998). Voluntary and Involuntary Minorities: A Cultural- Ecological Theory of School Performance with Some Implications for Education. Anthropology $\mathcal{E}$ Education Quarterly, 29 (2), 155-188.

[22] O'Higgins, N., \& Ivanov, A. (2006). Education and Employment Opportunities for the Roma. Comparative Economic Studies, 48, 6-19. 
[23] Puckett, L. M. (2005). Barriers to access. Social services and the Roma of Poland. International Social Work, 48 (5), 621-631.

[24] Ryu, M. (2009). Minorities in Higher Education. 2009 supplement. Washington, DC: American Council on Education.

[25] Safra, J.E., \& Yeshua, I. (2002). History of Education. In The New Encyclopaedia Britannica. (pp. 1-90). Chicago: Encyclopaedia Britannica, Inc.

[26] Taylor, B. (2014). Another Darkness, Another Dawn: A History of Gypsies, Roma and Travellers. London: Reaktion Books.

[27] Welch, A.R. (1988). Aboriginal Education as Internal Colonialism: The Schooling of an Indigenous Minority in Australia. Comparative Education, 24 (2), 203-21 